\title{
Translational control of ceruloplasmin gene expression: Beyond the IRE
}

\author{
BARSANJIT MAZUMDER ${ }^{1}$, PRABHA SAMPATH ${ }^{2}$ and PAUL L. FOX ${ }^{3}$
}

${ }^{1}$ Department of Biology, Cleveland State University, Cleveland, OH, ${ }^{2}$ Department of Pathology, University of Washington, Seattle, WA, USA, and ${ }^{3}$ Department of Cell Biology, Lerner Research Institute, Cleveland Clinic Foundation, Cleveland, OH, USA

\begin{abstract}
Translational control is a common regulatory mechanism for the expression of iron-related proteins. For example, three enzymes involved in erythrocyte development are regulated by three different control mechanisms: globin synthesis is modulated by heme-regulated translational inhibitor; erythroid 5-

aminolevulinate synthase translation is inhibited by binding of the iron regulatory protein to the iron response element in the 5'-untranslated region (UTR); and 15-lipoxygenase is regulated by specific proteins binding to the 3'-UTR. Ceruloplasmin (Cp) is a multi-functional, copper protein made primarily by the liver and by activated macrophages. $\mathrm{Cp}$ has important roles in iron homeostasis and in inflammation. Its role in iron metabolism was originally proposed because of its ferroxidase activity and because of its ability to stimulate iron loading into apo-transferrin and iron efflux from liver. We have shown that Cp mRNA is induced by interferon (IFN)- $\gamma$ in U937 monocytic cells, but synthesis of Cp protein is halted by translational silencing.

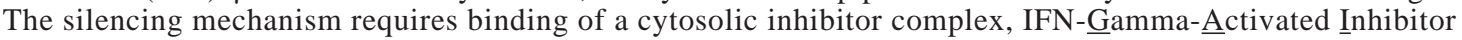
of Translation (GAIT), to a specific GAIT element in the Cp 3'-UTR. Here, we describe our studies that define and characterize the GAIT element and elucidate the specific trans-acting proteins that bind the GAIT element. Our experiments describe a new mechanism of translational control of an iron-related protein and may shed light on the role that macrophage-derived $\mathrm{Cp}$ plays at the intersection of iron homeostasis and inflammation.
\end{abstract}

Key terms: Translational control, ceruloplasmin, iron homeostasis, GAIT element, inflammation

Translational control of expression of proteins of iron metabolism

Actively translating mRNAs usually consist of (starting from the 5 '-end) an $\mathrm{m}^{7} \mathrm{GpppN}$ cap, a 5'-UTR, the coding region, a 3'-UTR, and a poly(A) tail. Translation is initiated by a sequence of events initiated by binding of a cap-binding complex, recruitment of the $43 \mathrm{~S}$ pre-initiation complex (containing the $40 \mathrm{~S}$ ribosomal subunit), scanning of the $43 \mathrm{~S}$ complex to the AUG initiation codon, and joining of the 60S large ribosomal subunit to form a translation-competent $80 \mathrm{~S}$ ribosome (Gebauer and Hentze, 2004). The rate of translation may be regulated by secondary control mechanisms of two types: global control in which synthesis of many or most proteins is regulated and transcript-selective control in which the synthesis of one (or several) protein(s) is regulated. Global protein synthesis is commonly inhibited by phosphorylation and reversible inactivation of a critical translation factor, eukaryotic translation initiation factor $2 \alpha(\mathrm{eIF} 2 \alpha)$. Four regulatable kinases are known to phosphorylate eIF $2 \alpha$ and inhibit global protein synthesis: heme-regulated translational inhibitor (HRI), which is activated by heme or iron deficiency; double-stranded RNA-regulated protein kinase (PKR), which is activated by viral

Correspondence: Paul L. Fox, Ph.D., Professor of Molecular Medicine, Department of Cell Biology / NC10, The Lerner Research Institute, Cleveland Clinic Foundation, 9500 Euclid Avenue, Cleveland, OH 44195, USA, Tel.: (1-216) 444-8053, Fax: (1-216) 444-9404, E-mail: foxp@ccf.org 
infection or double-stranded RNA; PKR-like endoplasmic reticulum (ER) kinase (PERK), which is activated by unfolded proteins in the ER; and GCN2, which is activated by amino acid deficiency (Dever, 2002). In most cases of transcript-selective regulation, translational control is dictated by binding of an RNA-binding protein to a cis-acting structural element in the 5'- or 3'-UTR of the target transcript. In eukaryotic cells, initiation is the usual regulated step, and protein/mRNA interactions generally repress, rather than activate, translation (Standart and Jackson, 1994).

Control of expression at the level of translation is a pervasive feature of metalcontaining and metal-related proteins. In fact, several major mechanisms of translational control were discovered in studies of these proteins. Iron deficiency has long been known to inhibit total (global) protein synthesis specifically in reticulocytes. This event is partly responsible for the hypochromic (hemoglobin-deficient) erythrocytes in irondeficiency in humans. As mentioned above, protein synthesis is blocked by activation of HRI, a heme-regulated eIF2 $\alpha$ kinase (Crosby et al., 1994). Phosphorylation of eIF2 $\alpha$ blocks the formation of the ternary complex (eIF2, GTP, and the charged initiator tRNA MettRNA $_{i}{ }^{\text {Met }}$ ) required for initiation of protein synthesis in all eukaryotic cells. The cell specificity of the inhibition results from the relatively specific localization of HRI in reticulocytes. Since globin mRNA is the major transcript in these cells, global inhibition of protein synthesis causes a dramatic decrease in globin synthesis and hemoglobin formation, the hallmark of irondeficiency anemia.

In the best-studied example of transcript-specific translational control, synthesis of multiple proteins of iron metabolism is regulated at the level of translation (Klausner et al., 1993). Included among these proteins are erythroid 5aminolevulinate synthase (eLAS), the ratelimiting enzyme in heme biosynthesis; ferroportin and divalent metal transporter 1 (DMT1), two key iron transporters; and ferritin, the cellular iron storage protein and the original protein in the family (Pantopoulos, 2004). The mechanism of this translational control has been investigated in detail. Iron deficiency induces the binding of an iron regulatory protein (IRP) to an iron-responsive element (IRE) in the 5'-untranslated region (UTR) of the mRNA. The IRE is a small stem-loop structure that lacks the thermodynamic stability on its own to block translation but, in conjunction with the IRP, blocks the association of the $43 \mathrm{~S}$ translation preinitiation complex (which contains the small ribosomal subunit) to the IREcontaining target mRNA (Gray and Hentze, 1994).

Control of 15-lipoxygenase (15-LOX) expression represents the third distinct translational control mechanism involving erythrocyte homeostasis. 15-LOX is responsible for red cell mitochondrial membrane breakdown, and its translation is inhibited specifically in erythroid precursor cells. The silencing mechanism involves binding of a complex of heterogeneous nuclear ribonucleoproteins (hnRNP) $\mathrm{K}$ and E1 to the differentiation control element (DICE) in the 3'-UTR of 15-LOX (Ostareck et al., 1997). Interaction of the regulatory complex with the 3'-UTR prevents joining of the $60 \mathrm{~S}$ ribosomal subunit at the AUG codon near the distant 5'-UTR of the transcript (Ostareck et al., 2001). hnRNP K is activated by ERK-mediated phosphorylation, which results in cytoplasmic accumulation and inhibition of 15-LOX translation (Habelhah et al., 2001). hnRNP $\mathrm{K}$ is inactivated by srcmediated phosphorylation, which then permits 15-LOX translation and breakdown of mitochondrial (and other) membranes required during late stages of reticulocyte maturation (Ostareck-Lederer et al., 2002).

\section{Ceruloplasmin and its Role in Iron Homeostasis and Inflammation}

Ceruloplasmin $(\mathrm{Cp})$ is an acute-phase plasma protein made by liver hepatocytes and by activated monocyte/macrophages. It is a 132 $\mathrm{kDa}$ monomer with amino acid sequence homology to Factors V and VIII of the coagulation cascade and to hephaestin, a recently discovered copper protein involved in intestinal iron absorption (Vulpe et al., 1999). Cp contains 6-7 copper atoms per 
molecule and accounts for $95 \%$ of the circulating copper in healthy adults. The mean, unevoked concentration in human serum is approximately $300 \mu \mathrm{g} / \mathrm{ml}$. The physiological function of $\mathrm{Cp}$ is uncertain, but roles in bactericidal activity, coagulation, iron homeostasis, vascular relaxation, defense against oxidant stress, and lipoprotein oxidation have been proposed (see Musci, 2001, for review). An elevated level of plasma $\mathrm{Cp}$ has been shown to be a risk factor for cardiovascular diseases, including atherosclerosis and myocardial infarction (Fox et al., 2000).

$\mathrm{Cp}$ is an important regulator of iron metabolism in vitro and in vivo. It is the principal plasma enzyme that catalyzes iron oxidation, and is required for efficient iron loading into apo-transferrin. The specific role of $\mathrm{Cp}$ in normal and pathological iron metabolism is not understood, but it can facilitate both cellular iron uptake (Attieh et al., 1999; Qian et al., 2001) or release (Harris et al., 1999; Sarkar et al., 2003). The important role of $\mathrm{Cp}$ in iron homeostasis in vivo has been confirmed by the discovery of debilitating iron overload in patients with aceruloplasminemia (i.e., hereditary $\mathrm{Cp}$ deficiency), an autosomal, recessive disorder caused by mutations in the coding region of the $\mathrm{Cp}$ gene that lead to complete absence of expressed protein (Xu et al., 2004). Massive iron overload in patients causes severe organ damage to the brain, retina, and other tissues. The important function of $\mathrm{Cp}$ in iron metabolism has been verified in mice with a targeted $\mathrm{Cp}$ gene deletion that also exhibit iron overload (Harris et al., 1999).

\section{Translational control of ceruloplasmin expression in monocyte/macrophages}

Hepatocytes are the principal source of plasma $\mathrm{Cp}$, but about 10 to $15 \%$ of circulating monocytes express $\mathrm{Cp}$ mRNA, as well (Yang et al., 1986). Several laboratories have shown that inflammatory mediators, e.g., tumor necrosis factor- $\alpha$ and yeast cell wall fragments, induce $\mathrm{Cp}$ mRNA and protein (Ehrenwald and Fox, 1996; Fleming et al., 1991). Thus, activated monocyte/macrophages are likely to be a major source of $\mathrm{Cp}$ in inflammatory sites. In our laboratory, we have investigated the "all-or-none" induction of $\mathrm{Cp}$ mRNA and protein by interferon (IFN) $-\gamma$ in human monocytic U937 cells (Mazumder et al., 1997). Surprisingly, Cp protein synthesis stopped abruptly and almost completely after about $16 \mathrm{~h}$ of IFN- $\gamma$ treatment, even in the presence of abundant transcript, a result consistent with translational silencing (Mazumder et al., 1997). Regulation at the level of translation was confirmed by pulselabeling experiments and by IFN-gmediated release of ribosomes from the $\mathrm{Cp}$ transcript, the latter finding consistent with an inhibition of translation-initiation (Mazumder and Fox, 1999). IFN- $\gamma$ did not inhibit total protein synthesis indicating a specific (or at least selective) inhibition of $\mathrm{Cp}$ translation. Translational silencing of $\mathrm{Cp}$ was cell type-specific and observed in multiple monocytic cell lines and in human peripheral blood monocytes but not in HepG2 cells or other cells investigated (Mazumder and Fox, 1999); silencing of GPI-linked Cp expressed by brain glial cells (Patel and David, 1997; Salzer et al., 1998) has not been studied to date. Initial studies showed that in vitro translation of $\mathrm{Cp}$ in a reticulocyte lysate was blocked by a protein or complex (termed IFN-GammaActivated Inhibitor of Translation, or GAIT) in the cytosolic lysate prepared from cells treated with IFN-g for $24 \mathrm{~h}$ (but not for $8 \mathrm{~h}$ ). Translational silencing was myeloid cell-specific, since cytosol from IFN-g-treated human peripheral blood monocytes inhibited $\mathrm{Cp}$ translation, but lysates from non-myeloid cells were ineffective. RNA electrophoretic mobility shift assay (EMSA) studies directly showed specific binding of GAIT to a radio-labeled probe consisting of the 256-nt Cp 3'-UTR.

\section{Identification of the GAIT translational control element in the CP 3'-UTR}

The GAIT-binding element in the Cp 3'UTR has been mapped by a series of progressive deletions from both ends. The minimal element that permitted GAIT binding in an RNA EMSA was a 29-nt element located between positions 78 and 
106 in the Cp 3'-UTR (Sampath et al., 2003). Folding analysis (by mFold) of the Cp 3'-UTR suggested that the Cp GAIT element contained a 5-nt apical loop, an asymmetric internal bulge consisting of 4and 2-nt loops, and two helical stems (Fig. 1, left). The principal features of this stem-loop structure were confirmed by mutational analysis; nucleotide substitutions that disrupted the putative stems inactivated the element, but covariant substitutions that restored complementarity also restored activity. The loop nucleotides were mutated one-by-one and tested by competition EMSA. Only two nucleotides (A84 and U87) were essential for binding activity, indicating that the structure of the element, not the sequence, is of critical importance in imparting specificity. A pattern analysis suggested that the GAIT structural element may be found in the 3'-UTR of other human transcripts (Sampath et al., 2003), but GAITmediated translational silencing of other mRNAs has not yet been shown. Hephaestin, a Cp paralog also involved in iron metabolism (but not inflammation) does not appear to contain the GAIT element. Superficially, the GAIT element bears some resemblance to other elements involved in metal metabolism (Fig. 1). It is slightly smaller than the minimal IRE, but about half the size of the selenocysteine insertion sequence (SECIS) element required for translational recoding of the UGA stop codon into selenocysteine insertion (Copeland and Driscoll, 2001). Interestingly, all three elements consist of pairs of stemloops, and all contain an invariant nucleotide in the central loop where it forms a "shoulder" with the distal stem.

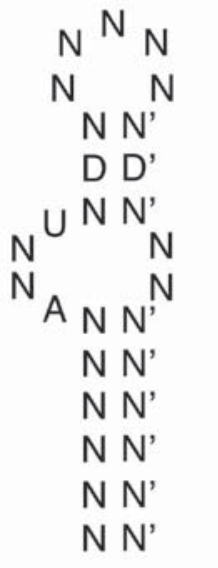

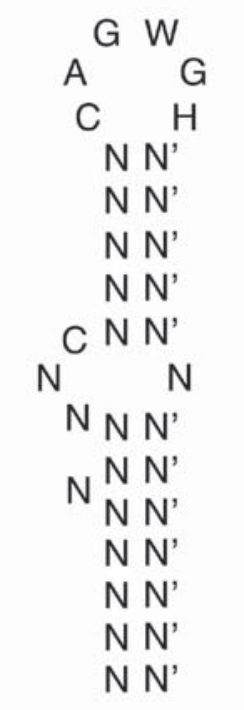

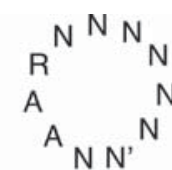

N N'

$N N^{\prime}$

$N N^{\prime}$

$\mathrm{N} \mathrm{N}^{\prime}$

$\mathrm{N} \mathrm{N}^{\prime}$

N N'

R Y

$\mathrm{R} Y$

N B

A G

G A

${ }^{N}{ }^{A}{ }^{A} N^{N} N^{N}$

$\mathrm{N} \mathrm{N}^{\prime}$

$\mathrm{N} \mathrm{N}^{\prime}$

$\mathrm{N} \mathrm{N}^{\prime}$

\begin{tabular}{|c|c|c|c|}
\hline Element: & GAIT & IRE & SECIS \\
\hline Location: & 3'-UTR & 5' or 3'-UTR & 3'-UTR \\
\hline $\begin{array}{c}\text { Binding } \\
\text { proteins: }\end{array}$ & $\begin{array}{c}\text { L13a, NSAP1, } \\
\text { EPRS, GAPDH }\end{array}$ & IRP-1, -2 & SBP2 \\
\hline Function: & $\downarrow$ Translation & $\begin{array}{c}\downarrow \text { Translation (5'), } \\
\text { mRNA stability (3') }\end{array}$ & $\begin{array}{c}\text { Selenocysteine } \\
\text { insertion }\end{array}$ \\
\hline
\end{tabular}

Figure 1. Comparison of structural RNA elements that regulate translation of proteins involved in metal homeostasis. 
The function of the GAIT element was confirmed by the translational silencing of a heterologous reporter transcript containing the luciferase open reading frame followed by the minimal 29-nt Cp 3'-UTR GAIT element and ending with a poly (A) tail (Luc-GAIT element-poly(A)). Cytosol from cells treated with IFN- $\gamma$ for $24 \mathrm{~h}$ completely inhibited translation of this construct but not a similar construct with the inactivating U87C mutation (Sampath et al., 2003). The chimeric construct showed that same sensitivity to inhibition as a construct containing the entire Cp 3'-UTR, indicating that the GAIT element is sufficient for the maximal response. A similar reporter construct driven by the CMV promoter was transfected into U937 cells, and its expression was inhibited after $24 \mathrm{~h}$ of IFN- $\gamma$ treatment, thus providing evidence for GAIT element function in cells.

\section{Mechanism of translational silencing of $\mathrm{Cp}$ Expression}

Understanding how 3'-UTR-binding proteins regulate translation at the distant 5 '-terminus has long perplexed investigators. An important clue came from studies suggesting a "closed-loop" or "circular" model of mRNA (Tarun and Sachs, 1995). Biochemical evidence for this model was provided by the discovery in yeast that poly(A)-binding protein (PABP) binds simultaneously to the 3'-located poly(A) tail and to the 5'-translationinitiation factor eIF4G, which interacts with cap-binding protein eIF4E, effectively circularizing the mRNA via end-to-end complex formation (Tarun and Sachs, 1995). The most compelling evidence for this model is its in vitro reconstitution and visualization by atomic force microscopy (Wells et al., 1998).

We tested two mechanisms of translational silencing of $\mathrm{Cp}$ : i) binding of GAIT to the GAIT element blocks mRNA circularization thereby inhibiting translation; and ii) inhibition of translation by GAIT requires mRNA circularization. To distinguish between these mechanisms, a chimeric reporter Luc-Cp 3'-UTR-poly(A) was subjected to in vitro translation. Cytosol from cells treated with IFN-g for $24 \mathrm{~h}$ blocked translation of this construct but did not inhibit the same construct without a poly(A) tail (Mazumder et al., 2001). The result suggests that the 2 nd mechanism is operative, since removal of the poly(A) tail, which disrupts transcript circularization, inhibits $\mathrm{Cp}$ translational silencing without inhibiting basal translation. This mechanism was supported by other disruptions of transcript circularization, e.g., depletion of PABP or inhibition of eIF4G/PABP interaction, which also blocked translational silencing of $\mathrm{Cp}$. These results indicate that translational silencing of $\mathrm{Cp}$ mRNA requires interactions between three essential elements of mRNA circularization: poly(A) tail, PABP, and eIF4G. According to one plausible mechanism, these interactions bring the inhibitory 3'-UTR binding protein into the vicinity of the translation-initiation site. Here, GAIT could interfere with initiation, possibly by competitive interactions with initiation factors or by blocking assembly of the $60 \mathrm{~S}$ and $40 \mathrm{~S}$ ribosomal subunits into a translationcompetent $80 \mathrm{~S}$ ribosome. It is possible, even likely, that a closed-loop requirement for translational control is common to other transcripts and control mechanisms; however, other examples have not been reported (Mazumder et al., 2003b).

\section{Identification of the protein components of GAIT}

Using genetic and biochemical approaches (Mazumder et al., 2003a; Sampath et al., 2004), we have identified four proteins in the GAIT complex: ribosomal protein L13a, glutamyl-prolyl-tRNA synthetase (EPRS), NS1-associated protein-1 (NSAP1), and glyceraldehyde 3-phosphate dehydrogenase (GAPDH). Assembly of the GAIT complex occurs in two temporally distinct stages (Fig. 2). During the early stage, which is complete within $4 \mathrm{~h}$, EPRS is phosphorylated and released from its residence in the aminoacyl-tRNA multisynthetase complex (Sampath et al., 2004). Phosphorylated EPRS interacts with NSAP1 to form a non-functional, pre-GAIT complex that does not bind the GAIT 
element. About 12-14 h later, L13a is phosphorylated and released from the large ribosomal subunit (Mazumder et al., 2003a). Released ribosomal protein L13a joins GAPDH and the pre-GAIT complex to form the functional GAIT complex that binds the 3'-UTR GAIT element of Cp mRNA and blocks its translation. Together, these results suggest a new paradigm in which ordinary housekeeping proteins, some mobilized from macromolecular parent complexes, assemble into extraordinary multisubunit structures with novel functions, in this case, inflammationresponsive translational control.

The function of delayed translational silencing of $\mathrm{Cp}$ is not known. An attractive possibility is suggested by the finding that $\mathrm{Cp}$ bactericidal activity is effective only in a narrow concentration range (Klebanoff, 1992). In this situation, overproduction of $\mathrm{Cp}$ could permit bacterial growth, possibly through adverse effects on iron homeostasis in the macrophage microenvironment. Alternatively, uncontrolled accumulation of $\mathrm{Cp}$ in inflammatory sites may have injurious consequences consistent with the ability of $\mathrm{Cp}$ copper to oxidize lipoproteins (Mukhopadhyay et al., 1997). The translational silencing mechanism may have evolved to limit macrophage expression of $\mathrm{Cp}$ and other inflammatory proteins. Interestingly, several mechanisms of inflammation-termination involve translational control. As an example, longterm activation by IFN- $\gamma$ may have adverse consequences on the cellular environment, and thus, IFN- $\gamma$ mRNA autoregulates its translation by formation of an RNA pseudoknot (Ben-Asouli et al., 2002). Likewise, we speculate that macrophage products of IFN- $\gamma$ activation, e.g. Cp, may have injurious consequences and require down-regulation. We further speculate that defects in any of the processes in GAIT complex formation could exacerbate macrophage production of $\mathrm{Cp}$ and delay or prevent the normal resolution of inflammation.

\section{ACKNOWLEDGEMENTS}

This work was supported by National Institutes of Health grants P01 HL29582, R01 HL67725, P01 HL76491 (to PLF), and R01 HL079164 (to BM), and by a Graduate Student Fellowship Award from the American Heart Association, Ohio Valley (to PS).

Time $=0$ to $4 \mathrm{~h}$ :

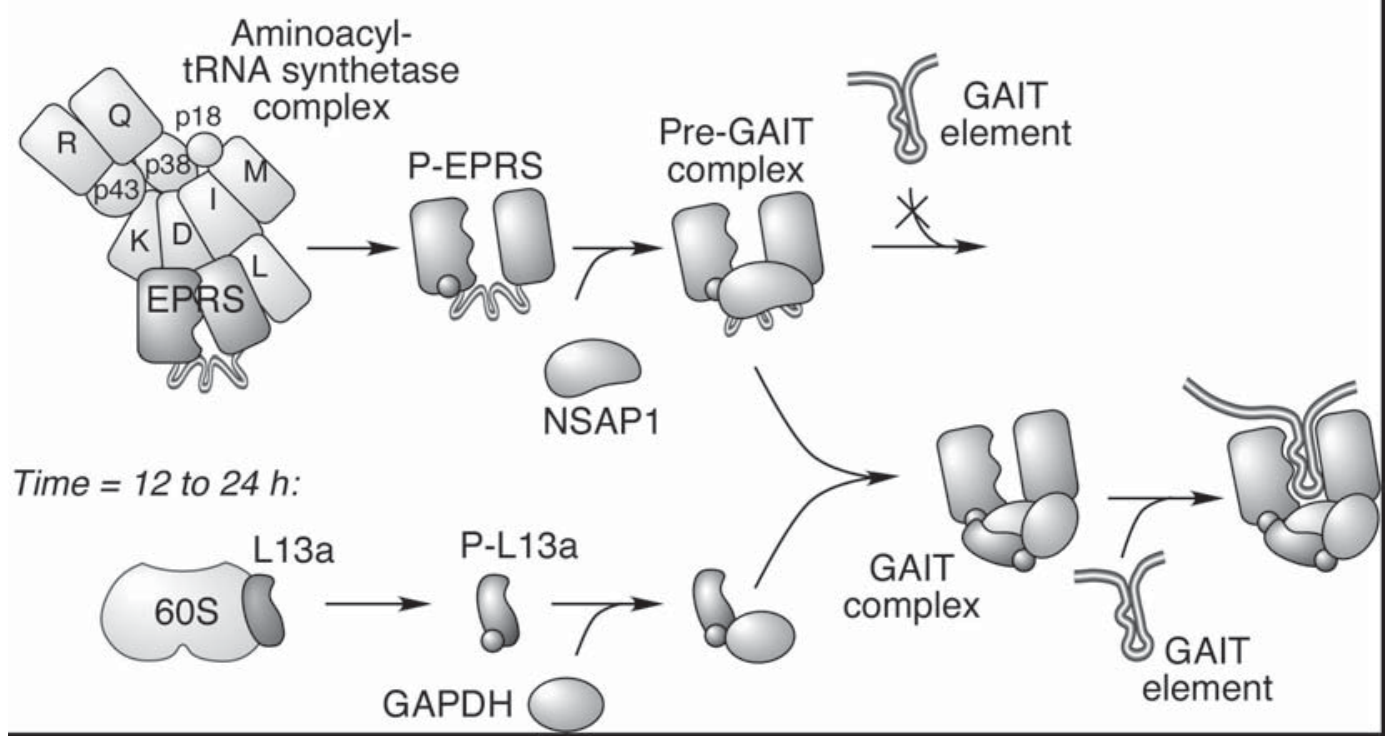

Figure 2. Schematic showing two-stage formation of GAIT complex and binding to GAIT element. 


\section{REFERENCES}

ATTIEH, Z. K., MUKHOPADHYAY, C. K., SESHADRI, V., TRIPOULAS, N. A., AND FOX, P. L. (1999). Ceruloplasmin ferroxidase activity stimulates cellular iron uptake by a trivalent cation-specific transport mechanism. J. Biol. Chem. 274, 1116-1123.

BEN-ASOULI, Y., BANAI, Y., PEL-OR, Y., SHIR, A., AND KAEMPFER, R. (2002). Human interferonmRNA autoregulates its translation through a pseudoknot that activates the interferon-inducible protein kinase PKR. Cell 108, 221-232.

COPELAND, P. R., AND DRISCOLL, D. M. (2001). RNA binding proteins and selenocysteine. Biofactors 14, 1116.

CROSBY, J. S., LEE, K., LONDON, I. M., AND CHEN, J. J. (1994). Erythroid expression of the heme-regulated eIF-2 $\alpha$ kinase. Mol. Cell. Biol. 14, 3906-3914.

DEVER, T. E. (2002). Gene-specific regulation by general translation factors. Cell 108, 545-556.

EHRENWALD, E., AND FOX, P. L. (1996). Role of endogenous ceruloplasmin in LDL oxidation by human U937 monocytic cells. J. Clin. Invest. 97, 884-890.

FLEMING, R. E., WHITMAN, I. P., AND GITLIN, J. D. (1991). Induction of ceruloplasmin gene expression in rat lung during inflammation and hyperoxia. Am. J. Physiol. 260, L68-L74.

FOX, P. L., MAZUMDER, B., EHRENWALD, E., AND MUKHOPADHYAY, C. K. (2000). Ceruloplasmin and cardiovascular disease. Free Radic. Biol. Med. 28, $1735-1744$

GEBAUER, F., AND HENTZE, M. W. (2004). Molecular mechanisms of translational control. Nat. Rev. Mol. Cell Biol.

GRAY, N. K., AND HENTZE, M. W. (1994). Iron regulatory protein prevents binding of the $43 \mathrm{~S}$ translation pre-initiation complex to ferritin and eALAS mRNAs. EMBO J. 13, 3882-3891.

HABELHAH, H., SHAH, K., HUANG, L., OSTARECKLEDERER, A., BURLINGAME, A. L., SHOKAT, K. M., HENTZE, M. W., AND RONAI, Z. (2001). ERK phosphorylation drives cytoplasmic accumulation of hnRNP-K and inhibition of mRNA translation. Nat. Cell Biol. 3, 325-330.

HARRIS, Z. L., DURLEY, A. P., MAN, T. K., AND GITLIN, J. D. (1999). Targeted gene disruption reveals an essential role for ceruloplasmin in cellular iron efflux. Proc. Natl. Acad. Sci. U. S. A. 96, 1081210817.

KLAUSNER, R. D., ROUAULT, T. A., AND HARFORD, J. B. (1993). Regulating the fate of mRNA: The control of cellular iron metabolism. Cell 72, 19-28.

KLEBANOFF, S. J. (1992). Bactericidal effect of $\mathrm{Fe}^{2+}$, ceruloplasmin, and phosphate. Arch. Biochem. Biophys. 295, 302-308.

MAZUMDER, B., AND FOX, P. L. (1999). Delayed translational silencing of ceruloplasmin transcript in gamma interferon-activated U937 monocytic cells: Role of the 3' untranslated region. Mol. Cell. Biol. 19, 6898-6905.

MAZUMDER, B., MUKHOPADHYAY, C. K., PROK, A., CATHCART, M. K., AND FOX, P. L. (1997). Induction of ceruloplasmin synthesis by IFN- $\gamma$ in human monocytic cells. J. Immunol. 159, 1938-1944.

MAZUMDER, B., SAMPATH, P., SESHADRI, V., MAITRA, R. K., DICORLETO, P., AND FOX, P. L. (2003a). Regulated release of L13a from the 60s ribosomal subunit as a mechanism of transcriptspecific translational control. Cell 115, 187-198.
MAZUMDER, B., SESHADRI, V., AND FOX, P. L. (2003b). Translational control by the 3'-UTR: the ends specify the means. Trends Biochem. Sci. 28, 91-98.

MAZUMDER, B., SESHADRI, V., IMATAKA, H., SONENBERG, N., AND FOX, P. L. (2001). Translational silencing of ceruloplasmin requires the essential elements of mRNA circularization: Poly(A) tail, poly(A)-binding protein, and eukaryotic translation initiation factor 4G. Mol. Cell. Biol. 21, 6440-6449.

MUKHOPADHYAY, C. K., MAZUMDER, B., LINDLEY, P. F., AND FOX, P. L. (1997). Identification of the prooxidant site of human ceruloplasmin: A model for oxidative damage by copper bound to protein surfaces. Proc. Natl. Acad. Sci. U. S. A. 94, 11546-11551.

MUSCI, G. (2001). Ceruloplasmin, the unique multi-copper oxidase of vertebrates. Protein Pept Lett 8, 159-169.

OSTARECK, D. H., OSTARECK-LEDERER, A., SHATSKY, I. N., AND HENTZE, M. W. (2001). Lipoxygenase mRNA silencing in erythroid differentiation: The 3'UTR regulatory complex controls 60S ribosomal subunit joining. Cell 104, 281-290.

OSTARECK, D. H., OSTARECK-LEDERER, A., WILM, M., THIELE, B. J., MANN, M., AND HENTZE, M. W. (1997). mRNA silencing in erythroid differentiation: hnRNP $\mathrm{K}$ and hnRNP E1 regulate 15-lipoxygenase translation from the 3' end. Cell 89, 597-606.

OSTARECK-LEDERER, A., OSTARECK, D. H., CANS, C., NEUBAUER, G., BOMSZTYK, K., SUPERTIFURGA, G., AND HENTZE, M. W. (2002). c-Srcmediated phosphorylation of hnRNP $\mathrm{K}$ drives translational activation of specifically silenced mRNAs. Mol. Cell. Biol. 22, 4535-4543.

PANTOPOULOS, K. (2004). Iron metabolism and the IRE/ IRP regulatory system: an update. Ann. N. Y. Acad. Sci. 1012, 1-13.

PATEL, B. N., AND DAVID, S. (1997). A novel glycosylphosphatidylinositol-anchored form of ceruloplasmin is expressed by mammalian astrocytes. J. Biol. Chem. 272, 20185-20190.

QIAN, Z. M., TSOI, Y. K., KE, Y., AND WONG, M. S. (2001). Ceruloplasmin promotes iron uptake rather than release in BT325 cells. Exp. Brain Res. 140, 369-374.

RABIZADEH, S., GRALLA, E. B., BORCHELT, D. R., GWINN, R., VALENTINE, J. S., SISODIA, S., WONG, P., LEE, M., HAHN, H., AND BREDESEN, D. E. (1995). Mutations associated with amyotrophic lateral sclerosis convert superoxide dismutase from an antiapoptotic gene to a proapoptotic gene: Studies in yeast and neural cells. Proc. Natl. Acad. Sci. U. S. A. 92, 3024-3028

SALZER, J. L., LOVEJOY, L., LINDER, M. C., AND ROSEN, C. (1998). Ran-2, a glial lineage marker, is a GPI-anchored form of ceruloplasmin. J. Neurosci. Res. 54, 147-157.

SAMPATH, P., MAZUMDER, B., SESHADRI, V., AND FOX, P. L. (2003). Transcript-selective translational silencing by gamma interferon is directed by a novel structural element in the ceruloplasmin mRNA 3, untranslated region. Mol. Cell. Biol. 23, 1509-1519.

SAMPATH, P., MAZUMDER, B., SESHADRI, V., GERBER, C. A., CHAVATTE, L., KINTER, M., TING, S. M., DIGNAM, J. D., KIM, S., DRISCOLL, D. M., AND FOX, P. L. (2004). Noncanonical function of glutamyl-prolyl-tRNA synthetase: gene-specific silencing of translation. Cell 119, 195-208.

SARKAR, J., SESHADRI, V., TRIPOULAS, N. A., KETTERER, M. E., AND FOX, P. L. (2003). Role of ceruloplasmin in macrophage iron efflux during hypoxia. J. Biol. Chem. 278, 44018-44024. 
SCHECHINGER, T., HARTMANN, H. J., AND WESER, U. (1986). Copper transport from $\mathrm{Cu}(\mathrm{I})$-thionein into apo-caeruloplasmin mediated by activated leucocytes. Biochem. J. 240, 281-283.

STANDART, N., AND JACKSON, R. J. (1994). Regulation of translation by specific protein/mRNA interactions. Biochimie 76, 867-879.

TARUN, S. Z., AND SACHS, A. B. (1995). A common function for mRNA 5' and 3' ends in translation initiation in yeast. Genes Dev. 9, 2997-3007.

VULPE, C. D., KUO, Y. M., MURPHY, T. L., COWLEY, L., ASKWITH, C., LIBINA, N., GITSCHIER, J., AND ANDERSON, G. J. (1999). Hephaestin, a ceruloplasmin homologue implicated in intestinal iron transport, is defective in the sla mouse. Nat. Genet. 21, 195-199.
WELLS, S. E., HILLNER, P. E., VALE, R. D., AND SACHS, A. B. (1998). Circularization of mRNA by eukaryotic translation initiation factors. Mol. Cell 2, $135-140$

XU, X., PIN, S., GATHINJI, M., FUCHS, R., AND HARRIS, Z. L. (2004). Aceruloplasminemia: An inherited neurodegenerative disease with impairment of iron homeostasis. Ann. N. Y. Acad. Sci. 1012, 299305.

YANG, F., NAYLOR, S. L., LUM, J. B., CUTSHAW, S., MCCOMBS, J. L., NABERHAUS, K. H., MCGILL, J. R., ADRIAN, G. S., MOORE, C. M., BARNETT, D. R., AND BOWMAN, B. H. (1986). Characterization, mapping, and expression of the human ceruloplasmin gene. Proc. Natl. Acad. Sci. U. S. A. 83, 3257-3261 